\title{
Nursing at Inflammatory Bowel Diseases
}

\author{
Berna Nilgun Ozgursoy Uran* and Elif Unsal Avdal \\ Izmir Katip Celebi University, Turkey
}

Submission: February 06, 2017; Published: February 27, 2017

"Corresponding author: Berna Nilgun Ozgursoy Uran, Associate professor, Izmir Katip Celebi University, Havaalanı Şosesi Cd. No: 33 D: 2, 35620 Çiğli/İzmir, Turkey, Email: bernanilgun@gmail.com

\section{Introduction}

Crohn's disease (CD) and ulcerative colitis (UC) encompass a multisystem group of disorders with specific clinical and pathological features characterized by focal, asymmetric, transmural, and occasionally, granulomatous inflammation primarily affecting the gastrointestinal tract [1]. These two diseases are called as Inflammatory Bowel Diseases (IBD).

IBD affect more than five million people worldwide, with 1.4 million in the US alone, and three million in Europe [2]. The incidence of IBD is increasing worldwide in adult and pediatric population, especially in traditionally low-incident regions such as Asia, South America and southern and eastern Europe [3-6]. In Turkey the incidence of UC is 2.6/100.000 and the incidence of CD is 1.4/100.000 [7]. Another study in Bolu/Duzce Region in Turkey, while the mean annual incidences were $0.99 / 105$ for UC, $0.45 / 105$ for CD between 2004-2005 years, they increased to $4.87 / 105$ and $2.09 / 105$ for ulcerative colitis and CD respectively between 2011-2013 years. While the prevalence was higher in urban areas in CD (12.60/105), it was higher in rural areas in UC $(36.17 / 105)[8,9]$.

It is important to closely monitore clinically. In the developed countries such as England, United States, United Kingdom, Australia, various activities are planned in order to train IBD specialized nurses and to increase the number of them. But developing countries do not even have IBD nurses.

IBD nurse is required who has an active role in the multidisciplinary team for IBD management, has the "expertise" authority and sufficient knowledge and skills in this regard. Therefore, we aim at explanation IBD nursing, IBD nurse's tasks and responsibilities in this review. In all IBD patients, effective symptom management, control of multiple drug use, continuous monitoring and close clinical follow-up are required.

Once the symptoms have been checked with effective symptom management and the remission has been reached, it is aimed to maintain the long-term remission and increase the quality of life $[10,11]$.

European Crohn's and Colitis Organisation (ECCO) has some sub-working groups. One of them is called Nurse-ECCO (N-ECCO). $\mathrm{N}$-ECCO group has prepared a consensus report describing the nursing roles in 2012. This report consists of three parts such as Fundamental IBD Nursing, Advanced IBD Nursing and The Perspectives of IBD Nursing [12].

The aims of this consensus are to identify the positioning of nurses in the care of patients with IBD and to provide a consensus on the ideal standard of minimum care that patients with IBD might expect, irrespective of the level of nurse training, title or country. The 'ideal' standard of nursing care was deemed an accurate measure and appropriate by the group in order to provide a standard for all nurses working with people with IBD [12].

IBD management is required a multidisciplinary approach consisting of doctors, nurses, dietitians, social workers and psychologists. In this team the nurse is also key roles. To play an active role of IBD nurse will contribute to an increase in effective disease management process and quality of life [13].

The nurse diagnoses according to the general condition of the patient, plans the blood-based care and turns the theoretical knowledge into practice. The nurse supports the patient and his/her family in the diagnosis and treatment process and plans the necessary trainings with the patient and his/her family. In addition, nurses should develop a constructive and empathic approach to special situations such as fistula, incontinence, sexuality, pregnancy and fertility, pain, fatigue. In order for nurses to fulfill these tasks successfully, they must be seen as part of a multidisciplinary team [14-17]. There are also some important topics in the job description of the nursing staff: providing nutritional support, performing training and counseling roles, defining and developing IBD services. 
Nursing knowledge is underlined in the report of N-ECCO. Nurses need to have basic knowledge of the diseases, know the difference between Crohn's disease and ulcerative colitis and appreciate the importance of establishing timely therapeutic interventions. Timely therapeutic intervention is essential for disease control.

Nurses caring for patients with IBD need an awareness of the extra-physical impact of the illness, of patients' key concerns, and the effect of IBD on health related quality of life [12].

Nursing involves advocacy and effective communication for all patients. These are of the utmost importance to patients with IBD due to the complex, uncertain and chronic nature of the condition. Communication is a two way process. Nurses need to develop an empathetic and active listening role, and be able to provide essential IBD-related information and holistic support [12].

An IBD nurse has been found to have an effective role in costeffective management of IBD. For example [12,18,19]:

A. Providing multidisciplinary team communication between primary and other institutions,

B. Supporting all aspects of patient and caregiver care in the hospital and community,

C. Rapid delivery of services to the nursing leadership, including clinical, telephone support and follow,

D. Managing and monitoring of immunosuppression, antiTNF therapy and nutritional support,

E. Developing research projects, ensuring supervision of projects and participating in projects to support the care of patients with IBD,

F. Making a teaching plan for the development and education of patients and health personnel for the management of IBD.

Specialist nurses working with patients with inflammatory bowel disease can perform these roles while working in polyclinics, medical and surgical clinics, primary care clinics and endoscopy units.Important roles such as clinical care, education, research, counseling, improving disease management, compliance and increasing patient satisfaction are also included in the IBD nursing [17]. Nurses have also important roles in patient education. Training is needed to activate and strengthen the patients and their family to live with IBD. The training program should include the basic information about the disease, nutrition and medical management, the importance of coming to regular checkups and disease coping skills, etc.

As in other chronicdiseases, nurse is responsible for the identification of the IBD. At the first meeting with a patient, an IBD nurse should get IBD history, because it is helpfull and necessary for patient. The N-ECCO Consensus statements aim to provide practical value at a local, national and international level in the development of nursingcare for patients with IBD. These statements are intended to be used as a means of in forming nurses, improving their knowledge and understanding and so raise the standard of care for patients with $[19,20]$.

\section{Conclusion}

Due to the many influences and uncertainties of the patients' lives, the nurse in the IBD management process should be counseled with holistic support and carry out a careful care process. In addition, the expert nurse should have adequate knowledge and skills in relation to the disease.

The other conclusion is about nursing training. Development of IBD nursing and post-graduate training programs should be supported. The dissemination of this area of expertise in nursing science and the support of the branching of the nurses will increase the quality of the care provided. Thus, the patients and their family will adapt to the disease, their self-efficacy levels and quality of life will be increased.

\section{References}

1. Lichtenstein GR, Hanauer SB, Sandborn WJ (2009) Practice Parameters Committee of the American College of Gastroenterology. Management of Crohn's Disease in Adults. Am J Gastroenterol 104(2): 465-483.

2. Burisch J, Jess T, Martinato M, Lakatos PL (2013) The burden of inflammatory bowel disease in Europe. J Crohn Colitis 7(4): 322-337.

3. Molodecky NA, Soon IS, Rabi DM, Ghali WA, Ferris M, Chernoff G, et al. (2012) Increasing incidence and prevalence of the inflammatory bowel diseases with time, based on systematic review. Gastroenterology 142(1): 46-54.

4. Benchimol EI, Fortinsky KJ, Gozdyra P, Van den Heuvel M, Van Limbergen J, et al. (2011) Epidemiology of pediatric inflammatory bowel disease: a systematic review of international trends. Inflamm Bowel Dis 17(1): 423-439.

5. Ng SC, Tang W, Ching JY, Wong M, Chow CM, et al. (2013) Incidence and phenotype of inflammatory bowel disease based on results from the Asia-pacific Crohn's and colitis epidemiology study. Gastroenterology 145(1): 158-165.e2.

6. Lovasz BD, Golovics PA, Vegh Z, Lakatos PL (2013) New trends in inflammatory bowel disease epidemiology and disease course in Eastern Europe. Dig Liver Dis 45(4): 269-276.

7. Tezel A, Dokmeci G, Eskiocak M, Umit H, Soylu AR (2003) Epidemiological features of ulcerative colitis in Trakya, Turkey. J Int Med Res 31(2): 141-148.

8. Can G, Posul E, Yilmaz B, Can H, Korkmaz U, et al. (2015) The rates of incidence and prevalence of inflammatory bowel diseases in Bolu/ Düzce Region: Retrospective cohort study between 2004-2013. Abant Med J 4(3): 210-220.

9. Mowat C, Cole A, Windsor A, Tariq Ahmad, Ian Arnott, et al. (2011) Guidelines for the management of inflammatory bowel disease in adults. Gut 60(5): 571-607.

10. (2012) National Institute for Health and Clinical Excellence (NICE) Guideline. Crohn's disease management in adults, children and young people, UK.

11. Stretton JG, Currie BK, Chauhan UK (2014) Inflammatory bowel disease nurses in Canada: An examination of Canadian Gastroenterology Nurses and Their Role in inflammatory bowel disease care. Can J Gastroenterol Hepatol 28(2): 89-93. 
12. O’Connor M, Bager P, Duncan J, Gaarenstroom J, Younge L, et al. (2013) $\mathrm{N}-\mathrm{ECCO}$ consensus statements on the European nursing roles in caring for patents with Crohn's disease or ulcerative colitis. Journal of Crohn's and Colitis 7(9): 744-764.

13. Ozgursoy Uran B, Yıldırım Y (2016) Yenibiruzmanlıkalanı: İnflamatuarbarsa khastalıklarıhemşireliği. İzmir Kâtip Çelebi Üniversitesi Sağlık Bilimleri Fakültesi Derg 1(2): 27-33.

14. Graff LA, Walker JR, Bernstein CN (2009) Depression and anxiety in inflammatory bowel disease: Review of comorbidity and management Inflamm Bowel Dis 15(7): 1105-1108.

15. Hernandez-Sampelayo P, Seoane M, Oltra L, Marín L, Torrejón A, et al. (2010) Contribution of nurses to the quality of care in management of inflammatory bowel disease: A synthesis of the evidence. Journal of Crohn's and Colitis 4(6): 611-622.

16. Mason I, Holbrook K, Kemp K, et al. (2012) Inflammatory bowel disease nursing: Results of an audit exploring the roles, responsibilities and activity of nurses with specialist/advanced roles. Royal College of Nursing, UK.

17. Stansfield C, Fraser A, Thompson J, Povey J (2007) Roles descriptives for inflammatory bowel disease nurse specialists-RCN guidance. Royal Collage of Nursing, UK.

18. Carter MJ, Lobo AJ, Travis SPL (2004) Guidelines for the management of inflammatory bowel disease in adults. Gut 53(Suppl 5): 1-16.

19. Greveson K, Woodward S (2013) Exploring the role of the inflammatory bowel disease nurse specialist. British Journal of Nursing 22(16): 1622.

20. Hernandez-Sampelayo P, Seoane M, Oltra L, Marín L, Torrejón A, et al. (2010) Contribution of nurses to the quality of care in management of inflammatory bowel disease: A synthesis of the evidence. Journal of Crohn's and Colitis 4(6): 611-622.

\section{Your next submission with Juniper Publishers will reach you the below assets}

- Quality Editorial service

- Swift Peer Review

- Reprints availability

- E-prints Service

- Manuscript Podcast for convenient understanding

- Global attainment for your research

- Manuscript accessibility in different formats ( Pdf, E-pub, Full Text, Audio)

- Unceasing customer service

Track the below URL for one-step submission https://juniperpublishers.com/online-submission.php 